\title{
Activities of the Consular Missions in Bosnia and Herzegovina in the First Years of the Austro-Hungarian Occupation 1878 - 1881*
}

\author{
AMILA KASUMOVIĆ** \\ Faculty of Philosophy, University of Sarajevo
}

\begin{abstract}
The system of capitulations was dominant from the $16^{\text {th }}$ century in economic and political relations of the Ottoman Empire and the European countries. Capitulations had always emphasized the right of foreign consuls to execute consular jurisdiction in the territory of the Ottoman Empire. Since the Eyalet of Bosnia was an integral part of the Ottoman Empire, the consular jurisdiction of foreign consuls included that area, which had especially become significant in the $19^{\text {th }}$ century when the leading European powers increasingly started to open their consulates in this part of the Empire. However, after Austria-Hungary occupied Bosnia in 1878, it aimed at terminating everything the capitulations contained regarding this area. The paper analyses the dynamics of termination of the consular jurisdiction of foreign consuls, the termination of the Austro-Hungarian consulates and the establishment of the new practice of appointment of foreign consuls in Bosnia and Herzegovina after 1878.
\end{abstract}

Key words: Bosnia and Herzegovina, Austria-Hungary, Ottoman Empire, capitulations, consular jurisdiction, consulates

After Article 25 of the Treaty of Berlin (1878) had granted a carte blanche to the Austro-Hungarian Monarchy to occupy and govern the territory of Bosnia and Herzegovina, significant changes occurred that meant that the occupied lands had to face some new circumstances and practises, while they were an enigma of a sort for legal professionals, almost a nonsense that needed to be solved. Issues concerning

\footnotetext{
* The paper published as: Djelatnost konzulata u Bosni i Hercegovini u prvim godinama austrougarske okupacije 1878-1881, Godišnjak Centra za balkanološka ispitivanja, br. 43, ANUBiH, Sarajevo 2014, 237-251.

"PhD. History Department. Email address: amila.kasumovic@ff.unsa.ba
} 
the Sultan's sovereignty over Bosnia and Herzegovina and the association of the occupied area to the administrative structure of the Monarchy were of the essence. Regarding the first issue, legal experts constructed two opposing theories, ${ }^{1}$ having analysed Article 25 of the Treaty of Berlin and provisions of the April Convention signed by the Monarchy and the Ottoman Empire on 21 April 1879. According to one of the theories, the Sultan was granted sovereignty over Bosnia and Herzegovina, ${ }^{2}$ while others saw it as the "naked right" (nudum ius) and deemed relevant only the results of the de facto rule over the area. ${ }^{3}$ The issue of the position of Bosnia and Herzegovina within the Monarchy remained, in a way, unsolved: this area was never integrated into the Monarchy, rather, it remained a special area within the Monarchy, i.e. something that was added to it - "zugewandt". ${ }^{4}$ Consular activities of different European powers, including Austria-Hungary, in Bosnia and Herzegovina after the Congress of Berlin (1878) posed another in a series of problems indicating the complicated and extremely interesting legal position of the occupied area at the turn of the $20^{\text {th }}$ century. In our research, we focused on the following three important segments related to this issue: 1 . consular jurisdiction of foreign consulates that was in force in the Eyalet of Bosnia; 2. appointment of foreign consuls in Bosnia and Herzegovina after 1878; and 3. termination of the k. u. $k .{ }^{5}$ consular offices of Austro-Hungary in the occupied area. ${ }^{6}$ An analysis of these three segments can show that Lingg's claim that the legal experts' stance on whether the Ottoman Sultan still had the sovereign right over Bosnia and Herzegovina did not matter, rather, the final answer to the sovereign right was the implemented politics of Austro-Hungarian administration which went in the direction of the increasingly tighter grip over the occupied area. ${ }^{7}$

${ }^{1}$ Calvo and Bluntschli are part of a special group of legal experts, since they did not clearly define their attitude towards the issue. For them, the position of Bosnia and Herzegovina was solved badly. Calvo even claimed that this was a new country of distinctive character. Imamović 1976, 21.

${ }^{2}$ Schneller 1893; Martens 1874.

${ }^{3}$ Lingg 1890.

${ }^{4}$ Halid Čaušević is of the opinion that until 1908 Bosnia and Herzegovina was a separate administrative area outside the Monarchy: de iure, the Sultan had sovereignty, but the factual execution of all sovereign rights was in the hands of the Monarchy. After 1908, Bosnia became a separate administrative unit within the Monarchy. Čaušević 1945, 137-139.

5 Translator's note: the abbreviation k. u. k. stands for kaiserlich und königlich in German, which translates as imperial and royal. The German abbreviation will be used throughout the text.

${ }^{6}$ Consular activity included many other activities this paper will not treat. The three aforementioned issues are the research interest of this topic.

${ }^{7}$ Lingg was of the opinion that the sovereign does not have legal, but factual administrative authority. See: Lingg 1890. 


\section{Termination of Consular Jurisdiction for Foreign Consulates in Bosnia and Herzegovina 1878 - 1881}

The issue of consular jurisdiction of foreign consulates on a foreign territory ${ }^{8}$ had been characteristic of the relationship between different European countries and the Ottoman Empire since the early modern period. It is closely linked to the issue of regulating the legal status of the müstemen in the Islamic countries. ${ }^{9}$ Müstemen were foreigners who were not citizens ${ }^{10}$ of an Islamic country, but were temporary residents. Their status under the Islamic and the Ottoman law was similar, but not equal to the legal status of the zimmis. They did not have legal and judicial independence until the $16^{\text {th }}$ century, more precisely, until Suleiman the Legislator (1520-1566) came to power. ${ }^{11}$ From the period of Sultan Suleiman's reign, capitulations were implemented, i.e. treaties that exempted certain persons from the rule and the law of the country in which they resided, while the consular representatives had a significant consular jurisdiction. ${ }^{12}$ Consulates were a judicial

${ }^{8}$ This has been a frequently treated topic. We will mention some works: Piskur 1862; Jacobovits 1865; Martens 1874; Lippmann 1898; Lang 1932; Kammerhofer 1996; Lopičić 2006.

${ }^{9}$ Aydin 2004, 581.

${ }^{10}$ In the used translation of the History of the Ottoman State and Civilisation, the term "citizen" was used. We are of the opinion that the use of this term is not suitable for the classical Ottoman period, since it is a relatively modern fact, dating to the late 18th century. In the original version of the aforementioned work, the expression used is tebaa, which translates as "subject". New Redhouse Turkish-English Dictionary 1968, 1111.

${ }^{11}$ Aydın 2004, 581. The zimmet (ar. dhimma) status was under the Sharia law and its implementation by authorities. The position of foreigners was regulated via international agreements and it depended on the balance of power between both countries (a Western country and the Ottoman Empire, AC). Braude / Lewis 2009, 59.

${ }^{12}$ Capitulation (Medieval Latin: capitulare: to agree) is, in a narrow sense, a term used for agreements that the European countries signed with the Ottoman Empire and other non-Christian countries. They contained benefits for their representatives, subjects and proteges. (Opća enciklopedija Jugoslovenskog leksikografskog zavoda 4, 1978, 264). The first capitulations were agreed between France and the Ottoman Empire in 1536. Ibrahim Pasha and Jean de La Forest, French Ambassador to the Ottoman Empire, participated in negotiations. However, these capitulations were not ratified. The legal base for the French presence in the Levant were the 1596 capitulations (Vejnstejn 2002, 266). In French, capitulations were called lettre patente. French capitulations from 1604 were, it seems, a model for all subsequent capitulations until the $19^{\text {th }} \mathrm{c}$. (McGowan 1981, 36). Capitulations were agreed with other countries as well: England (1580), Holland (1612), the Habsburg Monarchy (1616), while Sweden, Denmark, Prussia and Spain signed these agreements only in the 18th century (İpşirli 2004, 247). In the beginning, capitulations were primarily signed in order to provide support to these countries against the Habsburg Monarchy (İnalcık 2003, 216). Charles VI and Selim III signed a trade and maritime agreement in Požarevac, on 17 July 1718. The agreement enabled the Habsburg Monarchy to appoint consuls in all ports of the Ottoman Empire where representatives of foreign powers were present. In 1767, the Habsburg Monarchy already had three and by 1800 they had 21 consulate offices. The consulate general in Istanbul was open in 1846 (Agstner 2010, 137, 142-143). It is important to emphasise that the şeybülislam 
instance for solving disagreements among foreign nationals who lived in the Ottoman Empire. Litigations among foreign nationals and subjects of the Ottoman Empire were part of the jurisdiction of the Ottoman State. Müste'mens (foreigners) were granted certain privileges in case of litigation with subjects of the Ottoman Empire: the litigation could be settled at the sultan's divan, or monitored by an embassy officer from the country of the foreign national. ${ }^{13}$ Once it was decided in capitulations (Ottoman Turkish: ahdnâme, ahidnâme) to solve disputes among foreign nationals within their consulates, local authorities did not want to accept the hearings in such litigations (that had already been solved), even if one of the parties involved demanded it. ${ }^{14}$ From the mid- $18^{\text {th }}$ century, the issue of solving disputes between nationals of two different countries in the territory of the Ottoman Empire was regulated. In that case, disputes needed to be solved in the consular office of the country of the accused..$^{15}$

European countries' consular offices in Levant developed and grew more complex, especially in the $19^{\text {th }}$ century. Not only political reasons contributed to that, but also an increasing number of foreign nationals that settled or visited the Ottoman Empire. In that period, the opinion was that the consular protection of such persons was rather important. ${ }^{16}$ As the Eyalet of Bosnia was a constituent part of the Ottoman Empire, and keeping in mind its specific geopolitical position, the European powers in the $19^{\text {th }}$ c. started to open their consular offices there as well. ${ }^{17}$ Here too, one of the important functions of the consular missions was to protect the citizens and protégés of the country the consulate represented. When Herkalović lists the duties of a consular dragoman, he pays special attention to the issue of protection of the parties coming from the Habsburg Monarchy and were obliged to solve the dispute within the Ottoman judicial system (since the opposing party was an Ottoman

did not object capitulations in practice, although they could have stirred controversies in theory (Boogert 2005, 31). The practice of capitulations was recorded in the late $11^{\text {th }} \mathrm{c}$. when Venice and Genova signed this kind of agreement with the Byzantine Empire. (Kaser 2011,383)

${ }^{13}$ Aydin 2004, 581-582.

${ }^{14}$ That also concerned Venetian representatives, whose subjects had a special status in the Ottoman society. (Faroqhi 2004, 329) According to Article 3 of the French capitulations from 1536, consuls had jurisdiction over civil and criminal litigations among French subjects. They could ask for assistance of the Ottoman authorities, but, in principle, kadis and soubasi did not interfere. If a kadr suggested this kind of litigation, without previous demand by representatives of French authorities, the kadi's verdict would be annulled. (Boogert 2005, 35)

${ }^{15}$ Boogert 2005, 36.

${ }^{16}$ Although this remark concerned mainly the British subjects, we are of the opinion that it could be applied in the case of other European powers. (Berridge 2009, 78)

${ }^{17}$ There are many local historiographical works available on the foreign consulates. We will here mention some of the relevant titles: Zaplata 1937; Kreševljaković / Mitrović 1958; Petrović 1987; Šamić 1971; Tepić 1988; Kapidžić 1963; Radušić 2013; Madžar 1979. 
subject). The dragoman's duty was to serve as an interpreter to the parties on the one hand, and to supervise the litigation process and make sure that the hearings were conducted in accordance to the law on the other. ${ }^{18}$ In case the party represented was not satisfied with the decision, a protest was filed with the Ottoman authorities. The disputed decision would then be suspended and diplomatic skill used to reach a new settlement: the consulate general was obliged to send all acts related to the dispute, together with the report of the dragoman, to the embassy in Constantinople, with an urgency to obtain a just settlement with the Porte. ${ }^{19}$

The British consul in Bosnia had the right to preside over affairs of the British subjects, merchants and other persons that would come to this area of the Ottoman Empire. He could declare marriage between the British subjects, and, exceptionally, was also eligible to issue passports to the British subjects. However, it is very important to emphasise that he was making sure that the British subjects at the Ottoman court were treated in a "fair" manner. If he was unable to reach a satisfactory solution to a disputed issue, the consul was able to appeal to the ambassador in Constantinople so as to present the issue to higher Ottoman authorities. ${ }^{20}$ Since the Ottomans were not implementing the provisions contained in capitulations literally, the practice saw certain misuse or different interpretations of the rights and privileges granted to citizens of a European power. ${ }^{21}$

However, the situation changed after the Congress of Berlin and the occupation of Bosnia and Herzegovina by Austria-Hungary in 1878. Although the Second Military Region issued a circular on 23 December 1878 by which the AustroHungarian judicial practice implemented by the consulates in the country was to remain the same, as far as disputes between Austro-Hungarian citizens living in Bosnia and Herzegovina ${ }^{22}$ were concerned, an attitude was immediately formed that capitulations were only relevant with the "Muslim administration", but were inept in the European countries. ${ }^{23}$ The truth is that the idea of termination of consular

\footnotetext{
${ }^{18}$ Herkalović 1906, 25.

${ }^{19}$ Ibid., 26.

${ }^{20}$ Radušić 2013, 68, 71-72.

21 "The capitulations (...) should not be taken more seriously by the historian than they were by the Ottomans themselves. Even a slight acquaintance with the accounts of European travellers in the Levant will suffice to show how far actual diplomatic and commercial practice at the échelles differed from the texts deposited at Istanbul." McGowan 1981, 36. Osman Pasha complained that the consuls extensively referred to capitulations that were, in his opinion, reflections of lost battles. (Herkalović 1906, 27)

${ }^{22}$ Also, Austro-Hungarian citizens were to report to the consular authorities upon entering Bosnia and Herzegovina, within three days. Sammlung der für Bosnien und die Hercegovina erlassenen Gesetze, Verordnungen und Normalweisungen II, 1881, 62.

${ }^{23} \mathrm{ABiH}, \mathrm{ZMF}, 1879$, No. 481 (Joint Ministry of Finances - Württemberg, 18 February 1879. Vertraulich)
} 
jurisdiction of foreign powers in the area of Bosnia and Herzegovina was in the beginning taken with some reserve, for a simple reason: the court administration needed to be organised, personnel were to be appointed and a judicial system that would suit the new situation was to be established. ${ }^{24}$ The initial intention was to bring educated judges to the country, and then to solve the issue of terminating the consular jurisdiction ${ }^{25}$. Since certain steps had already been taken in that respect, this issue became prominent. Austria-Hungary followed Great Britain in the process, as they had similar dilemmas in Cyprus. ${ }^{26}$ To the very moment of the final decision, it was up to the Provincial Government to decide how to deal with foreign consulates. ${ }^{27}$ However, an opinion was offered that the consulates in Bosnia and Herzegovina should all have the same range of activity as those in the Monarchy, and that position would, in any case, exclude the legal jurisdiction of the consuls together with the rights and benefits they had in the Ottoman Empire. Generally, they emphasised the direction that should be taken in the future in order to move away from the Ottoman heritage, and that, again, meant that the consulates in the occupied area should as soon as possible be limited to the area of activity granted in the territory of the Monarchy. ${ }^{28}$ The Government of Great Britain, according to the Foreign Secretary Lord Salisbury's announcement to Karoly, had congruent attitudes to Hungarian and Austrian government. Still, Lord Salisbury was of the opinion that solving the issues of consular jurisdiction regarding other powers should wait a little longer, i.e. should be prolonged until the moment of abandonment of the areas of Romania and Bulgaria occupied by Russia. Lord Salisbury also insisted on the similarity of the situation in which Great Britain and Austria-Hungary were in, the former after the Cyprus occupation, and the latter because of the occupation of Bosnia and Herzegovina. For him, there was no option for foreign powers' governments to call upon capitulations in areas under the English rule. ${ }^{29}$

${ }^{24}$ According to what the British Consul Freeman wrote in September 1879, traces of a judicial organisation were barely seen. Personnel were missing and the officers from the Monarchy were volunteers. (Radušić 2011, 45)

${ }^{25}$ ABiH, ZMF, 1879, No. 479 (Joint Ministry of Finance - Karolyi in London, 18 February 1879)

${ }^{26}$ The position of Cyprus was not regulated by the accords of the Treaty of Berlin. Governments of Great Britain and the Ottoman Empire had signed a special agreement prior to the Congress of Berlin (4 June 1878) which, among other, stipulated that Cyprus would be occupée et administrée. (Geršić 1893, 7) However, the sultan's sovereignty on Cyprus had never been questioned, unlike Bosnia and Herzegovina. (Ibid., 19-20)

${ }^{27} \mathrm{ABiH}, \mathrm{ZMF}, 1879$, No. 481 (Joint Ministry of Finance - Württemberg, 18 February 1879. Vertraulich.)

${ }^{28}$ Ibid.

${ }^{29}$ Salisbury also presented to Karolyi a copy of a confidential dispatch he had sent to Lord Lyons on 16 January 1879, so that he could provide an adequate answer to the French Government regarding the issue of consular jurisdiction. The dispatch, among other, reads: "The Sultan has not ceded 
Apart from practical (organisation of judiciary) and foreign policy (the expected withdrawal of Russian troops from Romania and Bulgaria) factors that had postponed the final solution to the issue of consular jurisdiction in Bosnia and Herzegovina, there was another important factor that required attention - passing of a criminal code for the occupied area. ${ }^{30}$ Namely, the issue of the consular right to exercise jurisdiction depended on the introduction of the criminal law. The consulates' jurisdiction in criminal matters was limited but the following cases were exempted from jurisdiction of the Ottoman courts: a) when the perpetrator did not commit an offence against an Ottoman subject, b) when Ottoman interests were not affected, c) when the criminal act was not reported by the Ottoman security guard. ${ }^{31}$ That is why the minister-presidents from both sides of the Monarchy were asked to comment the issue. The matter was solved with the highest urgency. Already in mid-June 1879, the Provincial Government issued a decree aimed at instructing districts and courts regarding the issue of consular jurisdiction in civil matters. The decree stated that consular courts were competent in civil matters in which both parties were foreigners, in matters that concerned bankruptcy or testament of a foreign national (although one of the participants of the lawsuit could be a citizen of the Monarchy) and in cases when a foreign national was the accused and the national the plaintiff, if the latter agreed to a trial at the consular court. ${ }^{32}$ Lawsuits that concerned immovables were solved at courts in the country, as well as lawsuits in which nationals participated (except in the case of bankruptcy and testament of a foreign national). As far as lawsuits that concerned the national courts, where the accused, the plaintiff or a witness was a foreign national, the consul of the country of that citizen had a right to assistance but not of interference in the discussion. Executions of judgements against foreign nationals needed to be executed exclusively via consular representatives, even if courts of the country passed their decision. ${ }^{33}$

The measure was temporary, since negotiations with the German and the British governments were in progress, concerning the possibility of elimination of

Cyprus absolutely to Her Majesty, for it remains within the limits of the Ottoman Empire, and he has reserved the reversion of actual rule in a certain specified contingency. But for an indefinite time he has parted with the right of government, the right of legislation, and the right of making agreements with foreign powers. (...) So far as regards all the relation and transactions which the Capitulations touch, the cession is complete." ABiH, ZMF, 1879, No. 655 (Karolyi - Andrassy, 26 February 1879)

${ }^{30}$ The beginning of reorganisation of the legal situation in Bosnia and Herzegovina is linked to the introduction of a modern criminal law. (Eichler 189,169)

${ }^{31}$ ABiH, ZMF, 1879, No. 2356 (Joint Ministry of Finances - 1. Ministry of Foreign Affairs, 2. K. u. k. Minister President, 3. Hungarian Minister President, and 4. the Provincial Government, 14 June 1879)

${ }^{32}$ Sammlung, 1881, II, 63.

${ }^{33}$ Ibid. 
their consular jurisdiction in Bosnia and Herzegovina. The most important issue to the Austro-Hungarian Monarchy was to solve these issues with these powers. Encouraging news arrived from the German Reich in January 1880, when Count Széchényi from Berlin announced that the law was being drafted aimed to regulate the issue of German consular jurisdiction. The draft was waiting for an approval by the German Bundesrath (Federal Council) in April already. The German side was of the opinion that the Monarchy had taken all the measures necessary for the purpose of guaranteeing safety in the occupied area and that the consular protection (in this sense, $\mathrm{a} / \mathrm{n}$ ) was no longer necessary. Still, in the first phase, the total abolition of consular jurisdiction was not planned, but a possibility was left to limit it or to declare it void, depending on the decision of the Federal Council. ${ }^{34}$ Since the decision was not definitive, the entire matter was kept secret. The Ministry of Foreign Affairs informed the Joint Ministry of Finance in early May $1880 .{ }^{35}$ The German Reichstag approved the Draft Law on German Consular Jurisdiction in Bosnia and Herzegovina on 10 May. The Provincial Government was immediately informed through the Joint Ministry. ${ }^{36}$ The law was announced in the $14^{\text {th }}$ edition of the Imperial Gazette No. $1384 .{ }^{37}$ A new law was passed quickly which definitively terminated the German consular jurisdiction (Gazette No 1398, 23 December 1880). In just two articles of the law it was prescribed that the German consular jurisdiction would be put out of force starting 1 January 1881 . German citizens and protégés were from then on under the jurisdiction of the Monarchy, at courts that were established in the occupied territory and, it is important to emphasise, without any assistance from the consul or his representative. Legal disputes and criminal matters that had already been ongoing under the procedure of the consular court were to be resolved in accordance with the regulations in force until the law was passed. If the parties agreed to transfer such a dispute to courts in the country, they were able to do so. ${ }^{38}$ The German consular mission asked Wüttemberg to inform all political districts and courts in Bosnia and Herzegovina on the matter. ${ }^{39}$ That ended the termination of German consular jurisdiction.

${ }^{34}$ ABiH, ZMF, 1880, No. 2989 (Széchényi-Haymerle, 17 April 1880)

${ }^{35} \mathrm{Ibid}$. (The second submitted document: Ministry of foreign Affairs - Joint Ministry of Finance, 5 May 1880)

${ }^{36} \mathrm{ABiH}, \mathrm{ZMF}, 1880$, No. 3381 (Ministry of Foreign Affairs - Joint Ministry of Finance / Provincial Government, 19 June 1880)

${ }^{37}$ The text of the law was very short: "Die dem Konsul des Deutschen Reichs in Sarajewo für Bosnien Herzegovina zustehende Gerichtsbarkeit kann mit Zustimmung des Bundesraths durch Kaiserliche Verordnung eingeschränkt oder ausser Übung gesezt werden.” The Law was submitted to Szlavy on 22 July 1880, with a note from the Ministry of Foreign Affairs.

${ }^{38} \mathrm{ABiH}, \mathrm{ZV}, 1880$, box no. 7, code III/150.

${ }^{39} \mathrm{Ibid}$. 
The second important factor in the entire matter was the attitude of the British Government. However, it too was ready to cooperate. Lord Granville signed an act on 15 October 1880 that obliged Great Britain to terminate its consular jurisdiction in Bosnia and Herzegovina from 1 November $1880 . .^{40}$ The Ministry of Foreign Affairs asked Szlavy to instruct via telegram the Provincial Government on Granville's statement, with an emphasis that a shift in the date of the termination of the British consular jurisdiction could occur if the British consulate failed to receive instructions from its government. The telegram with special instructions was sent to the Provincial Government on 31 October $1880 .{ }^{41}$ It turned out that the Provincial Government had agreed with the British consul all that was necessary in order to implement this. Joint Ministry of Finance was able to approve the official announcement of the termination of the British consular jurisdiction. ${ }^{42}$ The Provincial Government printed a circular announcing the termination of the British consular jurisdiction The circular defined that the British consuls and subjects were only entitled to the rights that existed in the territory of the Monarchy and that in police and political-administrative matters in the occupied territory they would be treated just as they would be in the territory of the Monarchy. ${ }^{43}$

Governments of Italy, France and Russia followed the example of Britain and Germany. As a result, the Provincial Government sent a circular on 22 October 1881 announcing that these countries as well would waive their consular jurisdictions; their consulates would enjoy the same status as those in the Monarchy, and the proceedings initiated at the consular mission courts were to be solved in accordance with the norms that had been in force until to that point, unless the parties agreed to transfer the proceedings to the competent courts in the country. ${ }^{44}$

${ }^{40} \mathrm{ABiH}, \mathrm{ZMF}, 1880$, no. 7592 (Granville's signed document in appendix. The material handed over to Szlavy on 27 October 1880).

${ }^{41} \mathrm{ABiH}, \mathrm{ZMF}, 1880$, no. 7901 (Joint Ministry of Finance - the Provincial Government, 31 October 1880. The letter of the Ministry of Foreign Affairs dated 27 October is in the appendix.)

${ }^{42} \mathrm{ABiH}, \mathrm{ZMF}, 1880$, no. 7711 (Joint Ministry of Finance - 1. The Provincial Government; 2. Ministry of Foreign Affairs, 12 November 1880).

${ }^{43} \mathrm{ABiH}, \mathrm{ZV}, 1880$, box no. 7, code III/150, no. 27881 (The list of the British subjects submitted by consul Freeman on 6 November 1880 is in the appendix. The list contained only four names: 1. Adelina Paulina Irby, 2. Priscilla Hannah Johnston, 3. Emma Brooks and 4. Abdul Hamid. The name of the last person on the list was crossed with a remark that he was "a Turkish subject".) Cf. Sammlung 1881, II, 68. Copies of the circular were submitted to the Joint Ministry that then forwarded them to other addresses. ABiH, ZMF, 1880, no. 8662 (Joint Ministry of Finances 1. Ministry of Foreign Affairs, 2. K. u. k. Aust. Minister President and 3. Hungarian Minister president, 16 December 1880).

${ }^{44}$ Collection of laws and orders for Bosnia and Herzegovina 1881 (1906), 750. Sadly, although they existed, the documents that could provide us with an insight to the course of the negotiations about this issue with the governments of France, Italy and Russia are missing from the Archives of Bosnia and Herzegovina. 
Also, the issue of having jurisdiction over k. u. k. subjects in the area of Lim was also raised. The brigadier command in Pljevlja expressed the desire to transfer this jurisdiction, at least in the criminal offence cases, to the Military Judicial Subsidiary in Pljevlja. District courts in Čajniče and Višegrad would be competent for civil cases. The Ministry of War presented the proposal to the Ministry of Foreign Affairs, which then further presented it to the ministries of justice in both parts of the Monarchy, for the purpose of providing a competent answer. ${ }^{45}$ The answer stated, and the Ministry of War agreed, that consular jurisdiction over subjects that had come from the Monarchy be transferred to the civil committee and political officers with brigades. ${ }^{46}$ The circular presented by the Provincial Government on 3 October 1881 stating that the jurisdiction over Austro-Hungarian citizens be transferred to civil commissioners and the political officer with the $1^{\text {st }}$ Infantry Brigade definitively concluded the entire issue. The jurisdiction was in range that the k. u. k. general consulate had in Sarajevo, and the consular jurisdiction laws in the area of the Ottoman Empire were to be followed. ${ }^{47}$

The consular jurisdiction in the Ottoman Empire is another example of the clash of the titans - Occident vs. Orient - and interference into sovereignty rights. ${ }^{48} \mathrm{On}$ the other hand, it matches the stereotypes the West had towards the East, as well as the missionary task of the former to "civilise" the latter. That is why consular jurisdiction was frequently mentioned as an extremely important and necessary practice. ${ }^{49}$ The Ottomans themselves were aware of the negative influence of the practice. They tried to terminate it in 1914 , but the decision was nothing more than a dead letter. ${ }^{50}$ We can see that it had remained in force in the area of the Novi

${ }^{45} \mathrm{ABiH}, \mathrm{ZMF}, 1881$, No. 974. (Explanatory Document of the Ministry of Foreign Affairs, January 1881)

${ }^{46} \mathrm{ABiH}, \mathrm{ZMF}, 1881$, No. 5984 (Annex: Ministry of War, General Command, Sarajevo, 22 July 1881)

${ }^{47}$ Collection of laws and orders for Bosnia and Herzegovina 1881 (1906), 747.

48 "Disadvantages of the capitulations regime especially came to the surface regarding the issue of sovereignty of countries. In late $19^{\text {th }}$ and, especially, in the $20^{\text {th }}$ century, as per jurisdiction, the theory on state sovereignty developed, and, in consequence, the principle of territoriality (both public and private law) was increasingly established and spread. Namely, according to the principle of territoriality, the government of a country had administrative and judicial jurisdiction over all individuals, including foreign citizens, who were in the territory of a certain country. Apart from that, all public laws were applied in the country, and, to a certain extent, the public and private law. From that follows that the consular jurisdiction of a foreign country, based on capitulations, was considered a serious violation of sovereignty of another country to execute its authority (judicial, administrative or legal) in its territory." (Gašparović 2009, 688). Apart from that, the European countries started to claim right to the protection of a number of communities, which ultimately resulted in providing citizenship to many Christians and some Jews. (Braude / Lewis 2009, 60)

${ }^{49}$ Berridge 2009, 78 .

${ }^{50}$ Aydin 2004, 582. 
Pazar sanjak after 1878, while the area of Bosnia and Herzegovina in that sense was more tied to the practice of Austro-Hungary. In that way, the Monarchy had again violated the sovereignty in this area. ${ }^{51}$ The European powers silently supported such a state of affairs. They agreed to the termination of consular jurisdiction over its citizens in Bosnia and Herzegovina. In a broader perspective, they agreed to the termination of capitulations, although Article 8 of the Treaty of Berlin stipulated that all agreements signed by the Sublime Porte remain in power. ${ }^{52}$

\section{Appointment of Consuls of Foreign Powers in Bosnia and Herzegovina after 1878}

In the Ottoman period, consuls executed their duties in the territory of the Eyalet of Bosnia on the basis of imperial berats (exequatur) ${ }^{53}$ that granted their status and right to act in accordance with the powers they had. After the territory was occupied by Austria-Hungary, the issue arose regarding the fate of the consuls who had been appointed in the Ottoman period and the manner in which new consuls would be appointed.

In this case as well, the Monarchy followed the footsteps of the British Government in Cyprus. The Governor of British Cyprus was instructed to recognise the consuls who had received the exequatur prior to the occupation, while in the case of appointment of new consuls, the British Government issued the exequatur. The Joint Ministry of Finance agreed with the position of the British Government

${ }^{51}$ By terminating the consular jurisdiction in Bosnia and Herzegovina, the Monarchy directly indicated its future intentions regarding this area, although whether or not it had right to do so is disputable: “(...) wurden die von Österreich-Ungarn nach dem Vollzug der okkupation und Jahrzehnte vor der sog. Bosnischen Annexionskrise von 1908 getroffenen Re- gelungen, insbesondere die Einbeziehung in den gemeinsa- men Zollverband der Doppelmonarchie, die Aufhebung der Konsulargerichtsbarkeit und die Aushebung der mänlichen bosnischherzegowinischen Bevölkerung zugunsten der k. u. k. Armee, weder von der zeitgenössischen noch von der heutigen Literatur unter annexionsrechtlichen Gesichtspunkten bewertet." (Classen 2004, 118) Although Austro-Hungary violated the sultan's sovereignty in Bosnia and Herzegovina by its activities and administration, one cannot claim that boundaries did not exist in that sense. When in the second half of the 1880s Kállay advocated the emperor's visit to Bosnia, Kalnoky, the thenforeign affairs minister, opposed that "having taken into account the rise of possible diplomatic issues considering the sultan's sovereignty in Bosnia and Herzegovina." (Šehić 2013, 15).

${ }^{52}$ Imamović 1976, 24.

${ }^{53}$ Exequatur (Lat. exequi - to execute) - allowing a foreign country to allow the foreign representative (consul) to perform consular duties in its territory. (Klaić 1968, 32) Of course, consuls were appointed by their governments but the Ottoman beratl was necessary in order to present it to the local authorities and thus ensure the execution of the function. (Boogert 2005, 32) As an illustration, we will mention the example of Marko Dolinić (Markus Vuletić), the Austrian deputy consul in Mostar, for whom a ferman arrived in June 1850 to Ali Pasha Rizvanbegović and the then-kadı of Mostar, informing them that Dolinić was appointed deputy consul. (Grandits 2008, 482) 
regarding the foreign consuls' exequatur in Bosnia and Herzegovina and the national governor was instructed that way: all consuls in the Ottoman exequaturs (i.e. those that had received the exequatur prior to the occupation) had to be recognised in performing their functions; as for the appointment of new consuls, the Monarchy was in charge of issuing the exequaturs. ${ }^{54}$

Soon after the position to be taken regarding the appointment of foreign consuls in the occupied area was presented, the Ministry of Foreign Affairs asked Württemberg to recognise the appointment of Lodygensky as the Russian consul, and to let him execute his function. ${ }^{55}$ That was followed by the appointment of the then-serving British deputy consul in Mostar, Eduard Freeman, as the British consul. Württemberg was also asked to recognise this appointment and to allow the consul to execute his function. ${ }^{56}$

In the following year, the new French consul was appointed. First, in January, d'Hericourt assumed the position, replacing Patin, and a new change occurred in late May: Moreau, the former deputy consul in Janjina, replaced d'Hercourt. ${ }^{57}$ In June, Portugalés Gorgier was appointed deputy consul in Mostar. ${ }^{58}$ The Ministry of Foreign Affairs supervised the entire procedure and reported to the Joint Ministry of Finance, so that it further informed the Provincial Government with a plea to recognise the appointments and allow the consuls to execute their function. ${ }^{59}$

In April 1880, Paolo Riva was appointed Italian consul. ${ }^{60}$ In August that same year, a new Russian consul was appointed Modest Bakounin, who arrived to Sarajevo from Belgrade. He arrived as late as October and he was then issued the exequatur. ${ }^{61}$ Unlike the appointment of the Russian consul in 1879, this second appointment, it appears, caused a slight discomfort with the new administration in the occupied area. It seems that Württemberg asked for more instructions than ever before. There is a possibility

${ }^{54}$ ABiH, ZMF, 1879, No. 479 (Joint Ministry of Finances - Karolyi in London, 18 February 1879). Cf. Sammlung 1881, II, 62.

${ }^{55}$ ABiH, ZMF, 1879, No. 1892 (Preamble, 14 May 1879)

${ }^{56} \mathrm{ABiH}, \mathrm{ZMF}, 1879$, No. 1891 (Preamble, 14 May 1879). It seems that Freeman was a temporary consul. (Radušić 2013, 75)

${ }^{57}$ ABiH, ZMF, 1880, No. 91 (Joint Ministry of Finances - the Provincial Government, 9 January 1880. An annex was added to this document No. 3664, 11 June 1880). The Provincial Government presented the information to the Office of the Mayor in Sarajevo on 19 June 1880. Historical Archives Sarajevo, Office of the Mayor, 1880, No 3908.

${ }^{58}$ AMBiH, ZMF, 1880, No. 3883 (Preamble, 19 June 1880)

${ }^{59} \mathrm{ABiH}, \mathrm{ZMF}, 1880$, No. 91 (Joint Ministry of Finances - the Provincial Government, 9 January 1880. An annex was added to this document No. 3664, 11 June 1880)

${ }^{60} \mathrm{ABiH}$, ZMF, 1880, No. 91 (Joint Ministry of Finances - the Provincial Government, 11 April 1880)

${ }^{61} \mathrm{ABiH}, \mathrm{ZMF}, 1880$, No. 5590, 5976, 7073, 7165 (Correspondence between the Joint Ministry of Finances and the Provincial Government in the period from 18 August to 21 October 1880) 
that the head of the Provincial Government was reserved about the appointment of the new Russian consul, since the former consul, Lodygensky, had drawn the attention of the Police Directorate in Sarajevo with his behaviour. That had most probably cost him his consular position. Namely, Lodygensky clumsily stated that he would not hoist the Russian flag during holidays since that was not worth the trouble: according to the information he had and was not shy about presenting it publicly, he was to leave Sarajevo soon, since Austria and Russia were on the brink of a war. ${ }^{62}$ Apart from that, the Russian consul was close to the representatives of the church borough headed by Savo Kosanović. They organised meetings without previously informing the government's member of the board of the church borough..$^{63}$ The Russian consul linked to the Slovenian committee on behalf of which he had agitated against the new authority not only among Serbs, but Muslims as well. ${ }^{64}$ These circumstances had most probably influenced the position of Austro-Hungarian authorities regarding the appointment of the new consul. Time had shown that the new Russian consul Bakunin continued the work of his predecessor. ${ }^{65}$

Appointments of foreign consuls after the occupation of Bosnia and Herzegovina also showed the intention of the Monarchy to silently violate the sultan's sovereignty over the occupied area, originally guaranteed in the introductory section of the April convention.

\section{Termination of Austro-Hungarian Consular Offices in Bosnia and Herzegovina}

In the mid- $19^{\text {th }}$ century, the Habsburg Monarchy faced a financial meltdown. In order to overcome the situation, a reform programme had been initiated from 1859 which terminated the Ministry of Trade, Craftsmanship and Public Construction (Ministerium für Handel, Gewerbe und öffentliche Bauten). Consular issues entrusted to this ministry were transferred to the Ministry of Foreign Affairs in 1859. ${ }^{66}$ Consular affairs saw significant changes in the following ten years, especially

\footnotetext{
${ }^{62} \mathrm{He}$ also claimed to have been overseeing the activities of Austro-Hungarian authorities on behalf of the emperor, reporting directly to St. Petersburg. ABiH, ZMF, 1881, No. 1273 (Joint Ministry of Finances - Ministry of Foreign Affairs, 3 May 1880)

${ }^{63} \mathrm{ABiH}, \mathrm{ZMF}$, No. 5027 (A transcript of the report of the Head of the Police Directorate in Sarajevo, 18 July 1880)

${ }^{64}$ Kruševac 1960, 242-243.

${ }^{65}$ Ibid.

${ }^{66}$ Goldinger 1975 , 139. By 1859 , some of the consular offices were subjected to the Mnistry of Foreign Affairs: those in the Ottoman Empire, Greece and the General Consulate in Warsaw. Matsch 1986, 161.
} 
in 1868 and 1869, when the new consular organisation was established. ${ }^{67}$ In that period, there was a need for changes at the Oriental Academy. The basis for the change was the necessity to implement comprehensive legal education of the consular legal drafters. ${ }^{68}$ In 1870 , the Ministry of Foreign Affairs implemented the so-called consular survey that concerned also the aforementioned Academy (whether to keep it or not). The Ministry of Foreign Affairs' position that the Academy was useful prevailed and the delegations confirmed such a view. The Academy was preserved but was renamed to "K. u. K. Konsularakademie". ${ }^{9}$

One of the most important tasks of the Habsburg Monarchy's consuls was to implement consular jurisdiction. Decrees concerning the civil jurisdiction by k. u. k. consular offices were contained in the imperial decree from 29 January 1855 (RGB VII, No. 23), as well as in the decree by the Ministry of Foreign Affairs from 31 March that same year (RGB XVII, No. 58). K. u. k. consular missions were divided to those with full consular jurisdiction, like the ones in Constantinople, Jerusalem, Belgrade, Sarajevo, Mostar, etc., and to those with limited jurisdiction, like the consular missions in Banja Luka, Livno and some other towns. ${ }^{70}$ Consular courts had jurisdiction both over hearing and resolving civil proceedings related to trade and promissory note issues, as well as for bankruptcy issues. Appeals against the consular court decisions in Banja Luka, Livno, Mostar and Sarajevo were under the jurisdiction of the Supreme National Court in Zadar. ${ }^{71}$

Since Bosnia was part of the Ottoman Empire, consular missions of the Habsburg Monarchy were opened in this area (the Austrian consulate, renamed after the Austro-Hungarian settlement in the k. u k. Austro-Hungarian Consulate). The consulate was situated in Travnik for a very short while and then it was transferred to Sarajevo. The first Austrian consul general was dr. Dimitrije Atanasković. ${ }^{72}$ The consulate was politically and administratively subordinated to Constantinople and to the Ministry of Foreign Affairs as a higher instance. In civil law proceedings between Austrian subjects, the appeals went from the consular court to the Supreme National Court in Zadar; and in criminal proceedings (minor offences) the second and the last instance was the embassy in Constantinople; as for trading

${ }^{67}$ Malffati di monte Tretto 1879, (Vorwort) III.

${ }^{68}$ The original term is "Konzipiest". That was most probably the legal apprentice, a scrivener. (Klaić $1968,682)$

${ }^{69}$ Keeping the Oriental Academy proved correct. After the occupation of Bosnia and Herzegovina, some graduates from the academy were employed by the Provincial Government. (Matsch 1986, 102-103) See more about the Austrian consular jurisdiction in Bosnia in: Rill 1977.

${ }^{70}$ Malffati di monte Tretto 1879, 133-136.

${ }^{71}$ Ibid., 136-137.

${ }^{72}$ Austrian consulates and consular agencies were open in other places: Mostar, Livno, Banja Luka, Trebinje, Bihać, Tuzla and Brčko. (Zaplata 1937, 124) 
proceedings, the consulate was subordinated to the ministries of trade of both parts of the Monarchy. If an Austrian subject stood trial for a crime, the consulate would only have jurisdiction over preliminary investigation, while all records related to the issue were sent to the competent court in the Monarchy. ${ }^{73}$

After the Austro-Hungarian occupation of Bosnia and Herzegovina, the issue of the role and the function of the k. u. k. Austro-Hungarian consulates arose. In the beginning, they were to continue with the criminal law proceedings, but soon the prevailing attitude was that the time had come to terminate the Austro-Hungarian consulates in the interest of the national administration and that was something to strive for. ${ }^{74}$

In July, the possibility of transferring deputy consul Dragomanović (Livno) was considered, because there was a possibility that the Travnik district court or the Livno district office acting as court could assume consular jurisdiction. The Provincial Government was able to send an officer to deal with consular affairs, ${ }^{75}$ since it supported the aspirations of the Ministry of Foreign Affairs to solve the issue of the Livno consulate via a legal officer of the Provincial Government, who was specifically to cover judicial issues that were still arriving to the address of the consulate. In this way, the issue of replacement of unqualified or insufficiently qualified personnel, like the qadi, would be solved. Although the Livno kadı was considered competent, his unreliability contributed to the idea to appoint a properly trained officer from Sarajevo to that position. ${ }^{76}$ Deputy consul Josef Dragomanović was appointed provisional legal drafter of the Provincial Government and was to be transferred to Sarajevo to receive a decree of appointment, upon transferring the duty over to the Provincial Government's officer in Livno. ${ }^{77}$ Joint Ministry

${ }^{73}$ Ibid., 143.

${ }^{74}$ In cases when it was impossible to terminate the work at once, the transitional solution was that the consular jurisdiction over Austrian and Hungarian citizens was transferred to the educated judges as officers of the national administration, and in accordance with the norms applicable to the consular courts. ABiH, ZMF, 1879, No. 481 (Joint Ministry of Finances - Württemberg, 18 February 1879. Vertraulich). The British consul Freeman was of the opinion that the existence of Austro-Hungarian consular officers who still had judicial jurisdiction were an anomaly. (Radušić 2011,46)

${ }^{75} \mathrm{ABiH}, \mathrm{ZMF}, 1879$, No. 3534 (Joint Ministry of Finances - the Provincial Government, 21 July 1879)

${ }^{76}$ Perhaps an Austrian judge. ABiH, ZMF, 1879, No. 4227 (Joint Ministry of Finances - 1. Ministry of Foreign Affairs, 2. the Provincial Government, 25 August 1879)

77 The general intention was that the consular officers, following the closing of the consulates, be accepted to the service of the Provincial Government. The cases of Paul Peres, the provisional dragoman of the Mostar consulate, who had come to prominence because of discipline, fluency in Slavic languages and knowledge of the situation in the Ottoman Empire, and of Nicolaus Omčikus, the deputy consul in Brčko, were discussed. The Provincial Government was to pass the final decision. However, the government deemed both Peres and Omčikus unfit for service to the Provincial Government - the former was an old man and the latter was not only old 
of Finance insisted that the officer assuming the duty from Dragomanovic be an expert from the Monarchy. The ministry was also interested in the status of the officer who was to be appointed in Livno, as well as the date of his arrival and, ultimately, the payment Dragomanović would receive while serving the Provincial Government. ${ }^{78}$ The Provincial Government appointed Adolf Falkner to handle the affairs at the district office, but the final instructions related to the transfer of the consular agenda was the task of the Ministry of Foreign Affairs. ${ }^{79}$ In principle, it was sufficient to present this to the General Consulate in Sarajevo and the thendeputy consul in Livno, Dragomanović. He was acquainted with the procedure of transferring consular affairs to the Provincial Government's officer. ${ }^{80}$

In December, the transfer of the Banja Luka consulate took place. Deputy Consul Holzinger transferred the affairs to the district officer (Adjunkt $)^{81}$ Sedlnizki. Indeed, the "Livno case" did not initiate the superiors to precisely define his official status, which is what the Joint Ministry of Finance insisted on. The Ministry was of the opinion that the consular court was to be integrated to the district court or district area. This would reduce the material cost, Sedlnizki would be subordinated to the Provincial Government with regards to the judicial functions, and to the Supreme Court in Trieste with regards to consular affairs. Sedlnizki would not be subordinated to the General Consulate in Sarajevo, but directly to the Ministry of Foreign Affairs, but their correspondence would go via the Provincial Government. ${ }^{82}$

In January 1880, the Supreme Court presented the Banja Luka District Court report to the Provincial Government together with the protocols regarding the transfer of the consular agenda by the district officer Jaroslav, Baron von Sedlnizki. ${ }^{83}$

but also known for his lack of tact, and had an affair with a girl. The Provincial Government defended the attitude by a lack of finances. Deputy consul Müller worked for the Provincial Government, while Dragomanović was the second candidate to have been hired. Other consular officers were not interested in those positions. ABiH, ZMF, 1880, No. 609, No. 1129 and No. 1638 (Correspondence between the Joint Ministry of Finances and the Provincial Government, 7 February - 12 March 1880). The former deputy consul Müller was for a while a district prévôt in Mostar, and later also head of an administrative department at the Provincial Government. The former secretary of the embassy, Horoviz, was appointed the district prévôt in Tuzla. (Kraljačić $1987,442-443)$

${ }^{78} \mathrm{ABiH}, \mathrm{ZMF}, 1879$, No. 4705 (Joint Ministry of Finances - the Provincial Government, 26 September 1879)

${ }^{79} \mathrm{ABiH}, \mathrm{ZMF}, 1879$, No. 4912 (Joint Ministry of Finances - Ministry of Foreign Affairs, 2 October 1879)

${ }^{80} \mathrm{ABiH}, \mathrm{ZMF}, 1879$, No. 5095 (Ministry of Foreign Affairs' response, 7 October 1879)

${ }^{81}$ A lower-ranking official, trainee. (Klaić 1968, 13)

${ }^{82}$ ABiH, ZMF, 1879, No. 6612 (Joint Ministry of Finances - Ministry of Foreign Affairs, 31 December 1879)

${ }^{83} \mathrm{ABiH}, \mathrm{ZV}, 1880$, box 6 , code III/48 (Contains several documents related to the aforementioned transfer of power.) 
However, during the transfer of the consular agenda to the officers appointed by the Provincial Government, there arose another problem: the issuing of marriage licences to Austrian and Hungarian citizens. The Provincial Government favoured the termination of the k. u. k. consulates in the occupied area, hence, its opinion was that political districts with police registries were entitled to issue marriage licenses, because only proper insight into these registries could determine whether or not to issue the licence. Since both Austrian and Hungarian subjects still sought the licences at the k. u. k. consulates, the Provincial Government intended to issue a decree containing precise instructions as to who was competent for these matters. ${ }^{84}$ The problem was, most probably, a different standpoint of Austria and Hungary regarding this issue. The Hungarian Government was of the opinion that consulates should retain the right to issue marriage licences to Hungarian citizens in consulates, while Austrian citizens could obtain them in the okrug, possibly in the district areas, although the prévôt was from the Monarchy. That was the advice of the Austrian Government which also insisted that the marriage between two Austrian subjects should depend on two documents: a) an attestation on personal ability to enter marriage and b) political marriage license/permit. ${ }^{85}$ Still, the Joint Ministry of Finance hoped that the Hungarian Government would change its position and demanded the Provincial Government to cease the issuing of orders of any kind related to this matter. ${ }^{86}$ Since there had been no progress in solving the issue of marriage licenses, the Provincial Government issued a circular on 26 May 1880 stating that marriages between Austrian and Hungarian citizens was to be solved in accordance with the laws applicable depending on their indigeneity. ${ }^{87}$

The issue regarding the marriage licenses for subjects from the Monarchy could not have ceased the transfer of jurisdiction and affairs from consulates to the administrative organs in the country. Already in March 1880, the Provincial Government was ready to enter negotiations with the General Consulate in Sarajevo regarding the transfer of ongoing affairs, archives, office inventory and judicial deposits. Dahlen was of the opinion that the agendas from the Sarajevo, Mostar and Banja Luka consulates should be transferred to the district courts, while those from Livno and Brčko should be transferred to the kotar offices as courts in the aforementioned places. Of course, the burning problem was the staff and financing. That is why the proposal was to keep the consular fees that had been in place until

\footnotetext{
${ }^{84} \mathrm{ABiH}, \mathrm{ZMF}$, No. 5277 (Annexed to an 1880 document No. 749)

${ }^{85} \mathrm{ABiH}, \mathrm{ZMF}$, No. 5377 (Annexed to an 1880 document No. 749)

${ }^{86} \mathrm{ABiH}, \mathrm{ZMF}, 1879$, No. 749 (Joint Ministry of Finance - Hungarian minister president, 7 February 1880)

${ }^{87}$ Sammlung 1881, II, 69.
} 
then. ${ }^{88}$ Finally, the Joint Ministry of Finances announced an order definitively terminating the k. u. k. consulates in Bosnia and Herzegovina. Austrian and Hungarian citizens were to be treated in future in all political and administrative issues in the same was as the national subjects, in accordance with existing regulations. ${ }^{89}$ 1 April 1880 was the date from which political and judiciary areas in the country were to start taking all inquiries, requests, etc. that had previously been submitted to the consulates..$^{90}$ Secretaries of the government, Eichler and Kukuljević, oversaw the transfer procedure of the consular agendas in Sarajevo, while in Brčko that task was entrusted to officer Sukalić, in Banja Luka Sedlnizki, and to Falkner in Livno. Protocols were written during the transfer process that were sent to the Provincial Government. All parties whose disputes had not been solved at the consular courts had to be informed about the body competent for the disputes after 1 April. ${ }^{91}$ It had become evident that the transfer of competence would not meet the deadline, which suited the Joint Ministry, but the Provincial Government assured its superiors that the entire procedure would be completed by the end of April..$^{92}$ By that time, the manner in which the consular agendas would be transferred to different political and judiciary areas had already been determined: for example, the entire archives from the General Consulate in Sarajevo (year 1878, as well as parts of the 1879 and 1880 register where political and administrative issues were considered) was to be transferred to the I Department of the Provincial Government; criminal and legal issues, testaments, bankruptcies and civil processes under $500 \mathrm{fl}$. went to the Sarajevo District Court; acts and deposits related to civil disputes above $500 \mathrm{fl}$, as well as promissory note disputes went to the Sarajevo Supreme Court; acts on the requisitions of Austrian and Hungarian judicial areas went to the II Department of the Provincial Government, while acts and the requisition money of the tax areas

${ }^{88}$ ABiH, ZMF, 1880, No. 1498 (Dahlen - Joint Ministry of Finance, 3 March 1880). Ministry of Foreign Affairs was of the opinion that the Provincial Government, in the procedure of the transfer of consular affairs, needed to also prepare with regards to the space and the staff, but the Joint Ministry of Finance expressed the attitude that such preparations were not necessary since the districts could do the job within the existing field of action. ABiH, ZMF, 1880, No. 1403 (Telegram sent to Dahlen 5 March 1880)

${ }^{89}$ Sammlung 1881, II, 64-65. Cf. ABiH, ZMF, 1880, No. 1691 (Ministry of Foreign Affairs - Joint Ministry of Finances, 14 March 1880)

${ }^{90}$ Eichler 1889, 170.

${ }^{91}$ Sammlung 1881, II, 65.

${ }^{2}$ ABiH, ZMF, 1880, No. 1996 (Joint Ministry of Finances - the Provincial Government, 8 April 1880) and No. 2558 (Joint Ministry of Finances - Ministry of Foreign Affairs, 15 April 1880). Finally, the C. kr. Ministry of Finance announced on 20 April the information on the definitive and final termination of Austro-Hungarian consulates in the area of Bosnia and Herzegovina. (Verordnungsblatt für den Dienstbereich des k. k. Finanz- ministeriums für die im Reichsrathe vertretenen Königreiche und Länder 1880, 59) 
in the country went to the III department of the Provincial Government. ${ }^{93}$ After the termination of the k. u. k. consulates was almost complete, ${ }^{94}$ and the consular agendas found a new place within the fields of work of political and judicial competences, the Provincial Government issued a circular on 26 May 1880 by which it specified the method of treatment of the transferred material. Disputes that were assumed from the consular courts were to be solved by the laws applied by the consulates: the General Civil Code from 1811, the General Trading Code from 1862, and the General Promissory Note Ordinance from 1850. Laws of the country applied to disputes that started after 1 April. Bankruptcy procedures had to be conducted in accordance with the Ordinance on Bankruptcy from 1868. The Criminal code of Bosnia and Herzegovina was applied in criminal cases, unless the 1852 law (Monarchy) had more favourable provisions. ${ }^{95}$

Apart from all that has been said, the Provincial Government was also to assume from the consulates the task of drafting the trading reports twice a year, with a detailed reflection on the trading situation in the occupied area. ${ }^{96}$

Termination of Austro-Hungarian consulates in Bosnia and Herzegovina after the occupation is the third factor of linking this area to the Monarchy. It is clear that the sovereignty rights of the sultan over Bosnia and Herzegovina were breached.

\section{Conclusion}

"There is in addition the hegemony of European ideas about the Orient, themselves reiterating European superiority over Oriental backwardness, usually overriding the possibility that a more independent, or a more skeptical, thinker might have had different views on the matter." ${ }^{\text {"7 }}$ Indeed, the history of the relationship between the West and the East can be seen as a process in which the Orient has always and anew

\footnotetext{
${ }^{93}$ Similarly, the acts of other consulates were distributed (Sammlung 1881, II, 66-68) A section of confidential files was sent to Vienna by the Government order to dr. Ljudevit Thalloczy. Acts of other consulates were managed in a similar manner. (Zaplata 1937, 146-147)

${ }^{94}$ The Provincial Government submitted a comprehensive report to the Ministry of Finances. The report was then sent to the Ministry of Foreign Affairs. The Provincial Government submitted a request to have all copies of the Reichsgesetzblatt sent to it from 1 January 1880 . Since the Joint Ministry of Finance also shared the attitude of the Provincial Government that in dealing with Austrian and Hungarian citizens one needs to be acquainted with the legal affairs of the Monarchy, it advocated with the minister president that this gazette be sent to the Provincial Government in future. ABiH, ZMF, 1880, No. 4711 (Joint Ministry of Finance - 1. Ministry of Foreign Affairs, 2. Austrian Minister President and 3. Provincial Government, 21. July 1880)

${ }^{95}$ Sammlung 1881, II, 68-69.

${ }^{96}$ See more on the subject in: Kasumović 2013. Cf. ABiH, ZMF, 1880, No. 2080 and No. 2942 (Correspondence between the Joint Ministry of Finances and the Ministry of Foreign Affairs)

${ }^{97}$ Said 1999, 21.
} 
been Orientalized by westerners. The Occident and the Orient have been presented through dichotomies: strong - weak, rational - irrational, pure - wicked, mature - childish, normal - different. Since the Orient got the worst of this situation, it meant only one thing for westerners: the Orient was to be conquered again. That grand plan of conquering the Orient, of placing it in a subordinate position, unfolded at several levels. One of them was the system of capitulations that the Ottoman Empire had signed from the $16^{\text {th }}$ century with different western powers, and especially the important question of consular jurisdiction. This last issue indicates that the West had considered the East a dangerous area, and the Ottoman Empire a lawless country where foreigners had not been able to receive proper legal protection. That is why the consular jurisdiction of foreign powers over their subjects in the Ottoman Empire was considered an absolute necessity. It should be emphasized that such practice strongly intruded the sovereignty of the Ottoman state.

The existence of consular jurisdiction of foreign powers was present in the territory of Bosnia and Herzegovina since it was part of the Ottoman Empire and, as such, even in part, also part of the oriental circle. However, in Bosnia and Herzegovina, a reversed process took place after 1878, implemented by the new Austro-Hungarian administration. In a certain way, it had tried to de-orientalise the occupied territory. In the eyes of the "cultured" Europe, the process could have led only to a positive course. However, some of the lawyers who worked in the area rightly emphasised that some actions were directly threatening the sultan's sovereignty in the area of Bosnia and Herzegovina. Those actions, among other, included issuing permissions to the consuls to execute their function in the occupied area, and, in the further stage, terminating the consular jurisdiction of foreign consuls, and, finally, terminating the Austro-Hungarian consulates in the area. Thus, to the extent that the consular jurisdiction of foreign powers in the Ottoman area violated the sultan's sovereignty, the very termination of that jurisdiction in Bosnia and Herzegovina after 1878 violated the sultan's rights just as much, since the sultan himself was supposed to pass the decision on the appointment of the foreign consuls, as well as the decision on the termination of jurisdiction of the consuls. If the relationship of the Monarchy towards the occupied area was supposed to be seen as an issue of international law, then the Monarchy should have maintained the consulates in Bosnia. Since it terminated the consulates, it is clear that the relationship was raised to the level of state-legal matters. In that way, the sultan's sovereignty in the occupied area was only a dead letter. In practice, the Monarchy did everything it could to tie Bosnia and Herzegovina to its national framework. The European powers silently approved this, although Article 8 of the Treaty of Berlin stipulated that all agreements signed with the Sublime Porte, capitulations included, remain in force. According to the European statesmen in that period, the Monarchy was capable enough and civilised enough to properly look after foreign subjects in its territory. 


\section{Bibliography}

\section{Sources}

\section{Unpublished sources}

Arhiv Bosne i Hercegovine

Zajedničko ministarstvo finansija, opći spisi

Zemaljska vlada, opći spisi

Historijski arhiv Sarajevo

Gradsko poglavarstvo

\section{Published sources}

Sammlung der für Bosnien und die Hercegovina erlassenen Gesetze, Verordnungen und Normalweisungen, 1878-1880, II Band, Kaiserlich-königlichen Hofund Staatsdruckerei, Wien 1881.

Zbornik zakona i naredaba za Bosnu i Hercegovinu 1881, Sarajevo 1906.

Verordnungsblatt für den Dienstbereich des k. k. Finanzministeriums für die im Reichsrathe vertretenen Königreiche und Länder, Nr. 16, Wien 1880.

Kreševljaković, H. / Mitrović, P. 1958, Izvještaji italijanskog konzulata u Sarajevu (1863-1870). Sarajevo: Naučno društvo NR BiH.

\section{Literature}

Agstner, R. 2010, Zur Geschichte der österreichischen (österreichisch-ungarischen) Konsulate in der Türkei 1718-1918. U: Agstner, R./ Samsinger, E. (Hrsg.), Österreich in Istanbul. K. (u.) k. Präsenz im Osmanischen Reich. Wien-Berlin: Lit Verlag, 137-175.

Aydın, Â. M. 2004, Pravo kod Osmanlija. U: İhsanoğlu, E. (ur.), Historija osmanske države i civilizacije. Sarajevo: IRCICA / Orijentalni institut u Sarajevu, 515585.

Berridge, G. R. 2009, British Diplomacy in Turkey: 1583. to the Present (A study in the evolution of the resident embassy). Leiden: Martinus Nijhoff Publishers.

Boogert, M. H. van den 2005, The Capitulations and the Ottoman Legal System. Leiden-Boston: Brill.

Braude, B. / Lewis, B. 2009, Kršćani i Jevreji u Osmanskoj carevini. Funkcioniranje jednog pluralnog drustva. Sarajevo: CNS.

Classen, L. 2004, Der völkerrechtliche Status von Bosnie-Herzegowina nach dem Berliner Vertrag vom 13. 7. 1878. Frankfurt am Main: Peter Lang. 
Čaušević, H. 1945, Pravni položaj Bosne i Hercegovine pod Turskom i AustroUgarskom, Kalendar Narodna uzdanica, XIII, Sarajevo: "Narodna uzdanica”, 124-139.

Eichler, E. 1889, Das Justizwesen Bosniens und der Hercegovina. Wien: Landesregierung für Bosnien und die Hercegovina.

Faroqhi, S. 2004, The Venetian in the Ottoman Empire 1600-30. U: İslamoğluInan, H. (ed.), The Ottoman Empire and the World Economy. Cambridge: Cambridge University Press.

Gašparović, L. 2009, Osnove sustava kapitulacija kao međunarodnih ugovora sui generis u Osmanskom carstvu (XVI.-XVIII. st.), Zbornik Pravnogfakulteta $u$ Zagrebu, br. 4, Zagreb: Pravni fakultet Sveučilišsta u Zagrebu, 679-716.

Geršić, G. 1893, Pogled na medunarodni i državopravni položaj Bosne i Hercegovine i ostrva Kipra prema naučnim ocenama pretstavnika današnje mecunarodnopravne teorije, XXXVII, Beograd: Srpska kraljevska akademija.

Goldinger, W. 1975, Die Zentralverwaltung in Cisleithanien. Die zivile gemeinsame Zentralverwaltung. U: Wandruszka, A. / Urbanitsch, P. (Hrsg.), Die Habsburgermonarchie, Band II (Verwaltung und Rechtswesen). Wien: ÖAW, 100-190.

Grandits, H. 2008, Herrschaft und Loyalität in der spätosmanischen Gesellschaft. Das Beispiel der multikonfessionellen Herzegowina. Wien-Köln-Weimar: Böhlau Verlag.

Herkalović, T. 1906, Vorgeschichte der Occupation Bosniens und der Herzegovina. Zagreb: Druck von M. Majcen.

Imamović, M. 1976, Pravnipoložaj i unutrašnjopolitički razvitak BiH od 1878-1914. Sarajevo: Svjetlost.

İnalcik, H. 2009, Periods in Ottoman History, State, Society, Economy. U: Ínalcik, H. / Renda, G. (ed.), Ottoman Civilization 1. Ankara: Korza Printing House, 30-235.

İpşirli, M. 2004, Osmansko državno uređenje. U: İhsanoğlu, E. (ur.), Historija osmanske države $i$ civilizacije. Sarajevo: IRCICA / Orijentalni institut u Sarajevu.

Jacobovits, 1865, Die Consulate als Gerichtsbarkeiten im osmanischen Reiche. Wien: Braumüller.

Kammerhofer, L. 1996, Das Konsularwesen der Habsburgermonarchie (17521918). Ein Ueberblick mit Schwerpunkt auf Suedosteuropa. U: Heppner, H. (ed.): Der Weg führt über Österreich: Zur Geschichte des Verkehrs- und Nachrichtenwesens von und nach Südosteuropa (18. Jahrhundert bis zur Gegenwart). Wien: Böhlau, 7-35. 
Kapidžić, H. 1963, Sarajevo u augustu 1878 Izvještaj kraljevskog engleskog konzula njegovoj vladi, Prilozi za proućavanje istorije Sarajeva, I, Sarajevo: Muzej grada Sarajeva, 117-133.

Kaser, K. 2011, Balkan und Naher Osten-Einführung in eine gemeinsame Geschichte. Wien-Köln-Weimar: Böhlau Verlag.

Kasumović, A. 2013, Trgovina u Bosni i Hercegovini u svjetlu austrougarske zakonske regulative (1878-1914), Doktorska disertacija, Sarajevo: Filozofski fakultet Univerziteta u Sarajevu.

Klaić, B. 1968, Veliki rječnik stranih riječi, izraza i kratica. Zagreb: Zora.

Kraljačić, T. 1987, Kalajev režim u Bosni i Hercegovini 1882-1903. Sarajevo: Veselin Masleša.

Kruševac, T. 1960, Sarajevo pod austro-ugarskom upravom 1878-1918. Sarajevo: Muzej grada Sarajeva.

Lang, H. 1932, Das Konsul als Richter der freiwilligen Gerichtsbarkeit. Leipzig: Noske.

Lingg, E. 1890, Die staatsrechtliche Stellung Bosniens und der Herzegowina (Ein Beitrag zur Kritik der Lehre von den Staatenverbindungen). Freiburg: Archiv für öffentliches Recht-Fünfter Band. Herausgegeben von Dr. Paul Laband.

Lippmann, C. 1898, Die Konsularjurisdiction im Orient. Ihre historische Entwicklung von den fruehesten Zeiten bis zur Gegenwart. Leipzig: Veit.

Lopičić, Đ. N. (pr.) 2006, Studije i ogledi o konzularnim odnosima. Beograd: Samostalno priređivačko izdanje.

Madžar, B. 1979, Prikaz otpora austrougarskoj okupaciji 1878. u izvještajima njemačkog konzula. U: Ćemerlić, H. et al. (ur.), Naučni skup Otpor austrougarskoj okupaciji 1878. godine u Bosni i Hercegovini. Sarajevo: ANUBiH.

Malffati di Monte Tretto, J. 1879, Handbuch des österreichisch-ungarischen Consularwesens mit einer Sammlung von Normalien und einem Anhange über die Stellung der fremden Consular-Functionäre in Österreich-Ungarn, nach amtlichen Quellen. Wien: W. Braumüller.

Martens, F. F. 1874, Das Consularwesen und die Consularjurisdiction im Orient. Berlin: Weidmannsche Buchhandlung.

Matsch, E. 1986, Der auswärtige Dienst von Österreich (-Ungarn) 1720-1920. WienKöln-Graz: Böhlau.

McGowan, B. 1981, Economic Life in Ottoman Europe (Taxation, Trade and Struggle for Land 16001800). Cambridge: Cambridge University Press.

New Redhouse Turkish-English Dictionary, L-Z, Istanbul 1968.

Opća enciklopedija Jugoslovenskog leksikografskog zavoda, tom 4, Zagreb 1978. 
Petrović, R. 1987, Prvi diplomatski kontakti između Bosne i Hercegovine i Kraljevine Italije, Godišnjak Društva istoričara, XXXVIII, Sarajevo: Društvo istoričara $\mathrm{BiH}$.

Piskur, J. 1862, Oesterreichs Consularwesen. Wien: Gerold.

Radušić, E. 2011, Uspostavljanje austrougarske vlasti u Bosni i Hercegovini prema izvještajima konzulata u Sarajevu.U: Šehić, Z. (ur.), Bosna i Hercegovina u okviru Austro-Ugarske 1878-1918. Sarajevo: Filozofski fakultet u Sarajevu, 33-55.

Radušić, E. 2013, Bosna i Hercegovina u britanskoj politici 1857-1878. Od branitelja i zaštitnika do tužioca i sudije. Sarajevo: Institut za istoriju Sarajevo.

Rill, G. 1977, Zur Geschichte der österreichischen Konsulargerichtsbarkeit in Bosnien, Mitteilungen des Österreichischen Staatsarchiv, Band 30, Wien: ÖStA, 153-190.

Said, E. W. 1999, Orijentalizam. Sarajevo: Svjetlost.

Schneller, H. 1893, Državno-pravni položaj Bosne i Hercegovine (preveo M. $R$. Vesnić). Beograd: Izdanje fonda Ilije M. Kolarca.

Šamić, M. 1971, Otvaranje francuskog konzulata 1853. godine i boravak prvog konzula Eduarda Vjeta u Sarajevu, Radovi Filozofskog fakulteta, VI, 19701971, Sarajevo: Filozofski fakultet Univerziteta u Sarajevu, 473-479.

Šehić, Z. 2013, U mojoj Bosni (Povodom stogodišnjice posjete cara Franje Josipa I Bosni i Hercegovini od 30. maja do 4. juna 1910). Sarajevo: Dobra knjiga.

Tepić, I. 1988, Bosna i Hercegovina u ruskim izvorima (1856-1878). Sarajevo: Veselin Masleša.

Vejnstejn, Ž. 2002, Carstvo na vrhuncu moći XVI vek. U: Mantran, R. (ur.), Istorija osmanskog carstva. Beograd: Clio, 189-251.

Zaplata, R. 1937, Strani konzuli u Bosni i Hercegovini za turske vlade, Kalendar Gajret, Sarajevo: Gajret. 